\author{
MAgdalena Cyrek \\ Uniwersytet Rzeszowski, Polska \\ University of Rzeszów, Poland
}

\title{
Czynniki zmian produktywności w sekcjach działalności gospodarczej w Polsce
}

\section{Factors of Productivity Dynamics in Sections of Economic Activity in Poland}

\begin{abstract}
Streszczenie: Celem opracowania jest identyfikacja rodzajów działalności gospodarczej w Polsce o najwyższej dynamice produktywności oraz określenie źródeł tej dynamiki. Weryfikacji empirycznej poddaje się tezę o wyłanianiu się jednostek wiodących w sferze usług bazujących na wykorzystaniu wiedzy. W opracowaniu dokonuje się dekompozycji zmian produktywności z uwzględnieniem postępu technologicznego oraz efektywności technicznej. Ponadto porównuje się zmiany ogólnej produktywności, jak i produktywności poszczególnych nakładów: pracy prostej, kapitału fizycznego oraz kapitału ludzkiego, w ten sposób poszukując źródeł czynnikowych dynamiki rozwoju. Prezentowane badania dotyczą lat 2008-2016, a więc okresu ujawniania się i przełamywania ogólnoświatowych zjawisk kryzysowych. Realizację zadań badawczych oparto na zastosowaniu indeksu Malmquista i jego dekompozycji. Uzyskane wyniki pozwalają potwierdzić obecność tendencji do rozwoju usługowej gospodarki opartej na wiedzy w Polsce. Za współczesne jednostki motoryczne w kraju należy uznać sekcje: informacyjną, finansową, a także usługi profesjonalne. Identyfikacja tych sekcji jako charakteryzujących się korzystnymi zmianami produktywności i postępem technologicznym daje podstawy do kierunkowania polityki strukturalnej zapewniającej przyspieszenie tempa procesów wzrostowych. Ponadto zestawienie dynamiki produktywności poszczególnych czynników wytwórczych i jej dekompozycja pozwalają wskazać, że obecny etap zmian struktury wykorzystania zasobów produkcyjnych w Polsce przyjmuje raczej charakter ekstensywnego rozszerzania skali wykorzystania wiedzy.
\end{abstract}

\footnotetext{
Abstract: The aim of the study is to identify the types of economic activity in Poland that achieved the highest productivity dynamics, as well as to specify sources of the changes. It is empirically verified if the growth poles appear in a sphere of knowledge-based services. Decomposition of productivity changes into technological change and efficiency change is presented in the paper. Moreover, there are compared changes in total factor productivity, as well as changes in productivity of specified factors: labour, physical capital, and human capital and thus factoral sources of developmental dynamics are searched for. The presented research covers the period 2008-2016, that is specified by the appearance and breaking down the world economic crisis. To fulfil the research tasks the Malmquist index and its decomposition were used. The research results allow to confirm tendencies into a service knowledge-based economy's development in Poland. As modern growth poles should be recognised the following sections: information and communication; financial and insurance activities; professional, scientific and technical activities. Specifying such sections as those with favourable productivity changes and technological progress creates some basis to direct structural policy to accelerate economic growth. Moreover, comparison of productivity dynamics of productive factors and its decomposition allows to conclude that a modern phase of changes in a structure of productive factors' usage in Poland takes a form of extensive widening a range of knowledge use.
} 
Słowa kluczowe: czynniki produkcji; indeks Malmquista; sekcje działalności gospodarczej; zmiany produktywności

Keywords: factors of production; Malmquist index; productivity changes; sections of economic activity

Otrzymano: 5 grudnia 2018

Received: 5 December 2018

Zaakceptowano: 11 lutego 2019

Accepted: 11 February 2019

\section{Sugerowana cytacja / Suggested citation:}

Cyrek, M. (2019). Czynniki zmian produktywności w sekcjach działalności gospodarczej w Polsce. Prace Komisji Geografii Przemysłu Polskiego Towarzystwa Geograficznego, 33(1), 63-79. https://doi. org/10.24917/20801653.331.5

\section{WSTĘP}

Zmiany struktur sektorowo-branżowych są immanentną cechą procesów rozwoju społeczno-gospodarczego. Przekształcenia te często przybierają charakter polaryzacyjny, w którym pojawiające się motoryczne jednostki wzrostu o wysokiej dynamice technologicznej stają się źródłem modernizacji całej gospodarki ${ }^{1}$. Wyłaniające się na danym etapie rozwoju sektory wiodące stymulują wzrost gospodarczy i przesądzają o dominujących relacjach strukturalnych. Identyfikacja takich biegunów wzrostu jest przy tym zadaniem ciągłym ze względu na dynamikę współczesnych gospodarek, zmierzających w kierunku modelu usługowych gospodarek opartych na wiedzy. Poszukiwania nowych jednostek motorycznych wzrostu koncentrują się obecnie na sferze usługowej, w tym na usługach wiedzochłonnych i zaawansowanych technologicznie. Tym samym dość powszechnie kwestionuje się klasyczną tezę trójsektorową, zgodnie z którą sektor usług odznacza się najniższą podatnością na postęp technologiczny.

Analizy prezentowane w opracowaniu włączają się we wskazany szerszy nurt badań nad procesami przekształceń strukturalnych, który - jak wskazują E.G. Silva i A.A.C. Teixeira (2008) - w coraz większym stopniu kierunkowany jest obecnie na zagadnienia innowacji i stymulowanego technologicznie wzrostu gospodarczego. Przedstawiane w tekście badania koncentrują się na gospodarce Polski jako państwa z grupy państw odrabiających opóźnienia rozwojowe. W takich gospodarkach identyfikacja dziedzin i czynników dynamizujących procesy rozwojowe staje się szczególnie istotna z punktu widzenia racjonalnego kształtowania polityki ukierunkowanej na zmniejszanie luki technologicznej i strukturalnej. Wyniki badań stanowić mogą także przesłankę identyfikacji wzorców transformacji w kierunku usługowej gospodarki opartej na wiedzy dla państw pozostających na wcześniejszych etapach zmian strukturalnych.

Przedmiotem badań prezentowanych w opracowaniu są zmiany produktywności poszczególnych sekcji działalności gospodarczej lub ich agregatów w Polsce, definiowanych zgodnie z układem PKD 2007 (NACE Rev. 2). Wyodrębnia się 16 takich agregatów:

- AB - Rolnictwo, leśnictwo, łowiectwo i rybactwo; Górnictwo i wydobywanie,

- C - Przetwórstwo przemysłowe,

\footnotetext{
${ }^{1}$ Koncepcję tzw. jednostek motorycznych, które odpowiadają sektorowym biegunom wzrostu, wprowadził do dyskursu naukowego jeszcze w latach pięćdziesiątych XX wieku J. Perroux. W opracowaniu identyfikuje się jednostki motoryczne, określane również jako jednostki/sektory wiodące lub bieguny wzrostu, poprzez ocenę dynamiki produktywności na poziomie agregatów sekcyjnych.
} 
- DEF - Wytwarzanie i zaopatrywanie w energię elektryczną, gaz, parę wodną, gorącą wodę i powietrze do układów klimatyzacyjnych; Dostawa wody; Gospodarowanie ściekami i odpadami oraz działalność związana z rekultywacją; Budownictwo,

- G - Handel hurtowy i detaliczny; naprawa pojazdów samochodowych, włączając motocykle,

- H - Transport i gospodarka magazynowa,

- I - Działalność związana z zakwaterowaniem i usługami gastronomicznymi,

- J - Informacja i komunikacja,

- K - Działalność finansowa i ubezpieczeniowa,

- L - Działalność związana z obsługą rynku nieruchomości,

- M - Działalność profesjonalna, naukowa i techniczna,

- N - Działalność w zakresie usług administrowania i działalność wspierająca,

- OU - Administracja publiczna i obrona narodowa; obowiązkowe ubezpieczenia społeczne; Organizacje i zespoły eksterytorialne,

- P - Edukacja,

- Q - Ochrona zdrowia i pomoc społeczna,

- R - Działalność związana z kulturą (rozrywką i rekreacją),

- ST - Pozostała działalność usługowa; Gospodarstwa domowe zatrudniające pracowników; Gospodarstwa domowe produkujące wyroby i świadczące usługi na własne potrzeby.

Grupowanie poszczególnych sekcji nie tylko wynika z ograniczonej dostępności danych statystycznych, ale i znajduje uzasadnienie w specyfice realizowanej działalności gospodarczej. Agregat sekcji A i B jest adekwatny do działalności określanej jako sektor I w klasycznej teorii rozwoju trójsektorowego sformułowanej przez A. Fishera (1935) i C. Clarka (1940) i dotyczy działalności polegającej na pozyskiwaniu przez człowieka zasobów natury. Agregat sekcji D, E i F ma charakter funkcyjny, związany z zaspokajaniem podstawowych potrzeb bytowych społeczności, głównie komunalno-mieszkaniowych, a jednocześnie cechuje się przewagą kapitałochłonnych metod produkcji. Agregat sekcji 0 i U bezpośrednio łączy się z realizacją funkcji władzy publicznej w wewnętrznych i zewnętrznych relacjach państwa. Agregat ST ma głównie charakter rezydualny, przy czym jego skala gospodarcza jest marginalna.

Zasadniczym celem prezentowanych badań jest identyfikacja tych rodzajów działalności, które odznaczają się najwyższą dynamiką produktywności, a więc stanowić mogą o przyspieszeniu rozwoju całej gospodarki. Jednocześnie poszukuje się źródeł zmian produktywności o charakterze technologicznym oraz czynnikowym. Zestawienie zmian produktywności ogólnej uzupełnione jest o zmiany produktywności poszczególnych czynników wytwórczych w układzie: kapitał fizyczny, praca prosta oraz kapitał ludzki.

Realizację tak określonych zadań badawczych oparto na zastosowaniu indeksu Malmquista i jego dekompozycji w ujęciu R. Färe’a, S. Grosskopf, M. Norris i Z. Zhanga (1994) na efekt postępu technologicznego i efekt zmian efektywności technicznej, w tym jego składowych: czystej efektywności technicznej oraz efektu skali. Wykorzystano nieparametryczną metodę DEA (model CRS) oceny efektywności poszczególnych sekcji (w ujęciu 16 agregatów). Obliczenia przeprowadzono z wykorzystaniem programu DEAP 2.1. W zastosowanych modelach uwzględniono cztery zmienne: 
- wyniki w postaci wytworzonej produkcji, za której miernik przyjęto wartość dodaną brutto wyrażoną w milionach złotych w cenach stałych z 2010 roku (Eurostat, 2018 [nama_10_a64]),

- nakłady kapitału fizycznego, przybliżanego poprzez wartość zużycia środków trwałych wyrażoną w milionach złotych w cenach stałych z 2010 roku (Eurostat, 2018 [nama_10_a64]),

- nakłady pracy prostej, określone jako różnica pomiędzy ogólnym zatrudnieniem w tysiącach osób (Eurostat, 2018 [nama_10_a64e]) a liczbą osób zatrudnionych (w tysiącach) $\mathrm{z}$ wykształceniem wyższym według klasyfikacji ISCED (Eurostat, 2018 [hrst_st_nsec2]),

- nakłady kapitału ludzkiego, za których wyznacznik przyjęto liczbę osób zatrudnionych (w tysiącach) z wykształceniem wyższym według klasyfikacji ISCED (Eurostat, 2018 [hrst_st_nsec2]).

Wszystkie dane zaczerpnięto z bazy danych statystycznych Eurostat.

Analizy obejmują lata 2008-2016, a więc okres ujawniania się i przełamywania ogólnoświatowych zjawisk kryzysowych. W okresach kryzysowych dynamizacji podlegają zmiany strukturalne i często wyłaniają się nowe bieguny rozwojowe, a rozpoznanie tych tendencji nabiera szczególnego znaczenia wobec konieczności zniwelowania przez Polskę dystansu rozwojowego względem najbardziej zaawansowanych gospodarek UE i świata.

\section{KONCEPCJA I POMIAR PRODUKTYWNOŚCI ORAZ JEJ DYNAMIKI}

Koncepcja produktywności jest jednym z podstawowych aspektów rachunku ekonomicznego, który stanowi podstawę decyzyjną dla optymalizacji zachowań gospodarczych w skali zarówno mikro-, jak i makroekonomicznej. Produktywność definiowana jest jako relacja wyników do nakładów, wskazując, jakie efekty produkcyjne mogą zostać uzyskane z danego poziomu nakładów (Kaasa, 2016: 12). Wzrost produktywności ma miejsce, gdy zmniejsza się skala nakładów przy zachowaniu stałego poziomu wyników (opcja oszczędnościowa) lub też gdy wzrasta wielkość wyników przy utrzymaniu nakładów na niezmienionym poziomie (opcja wydajnościowa). W zależności od liczby uwzględnianych nakładów wyróżniane są: produktywność ogólna (wieloczynnikowa, TFP) oraz cząstkowa (czynnikowa), uwzględniająca konkretny typ nakładów (produktywność pracy, produktywność kapitału itp.). Kompleksowe analizy produktywności powinny przy tym uwzględniać oba typy mierników (Murray, 2016).

W praktyce badań ekonomicznych najczęściej uwzględnia się różnorodne czynniki wytwórcze uczestniczące w procesach produkcji, przy czym ze względu na współczesny etap zaawansowania rozwoju społeczno-gospodarczego klasyczna triada ziemia - praca - kapitał jest zastępowana nakładami o dominującej obecnie roli, a więc kapitałem fizycznym oraz ludzkim. Przykładowo, E.M. Ahmed i G. Krishnasamy (2013) dokonują dekompozycji zmian produktywności w gospodarkach państw ASEAN, uwzględniając model, w którym efekty w postaci realnego PKB odnoszone są do nakładów kapitału fizycznego (mierzonego realnymi nakładami brutto na środki trwałe), pracy (określanej przez zatrudnienie ogółem) oraz kapitału ludzkiego (przybliżanego przez realne nakłady na edukację). S. Gitto i P. Mancuso (2015) przedstawiają natomiast dekompozycję dynamiki produktywności pracy (w ujęciu wartości dodanej brutto na zatrudnionego) 
we włoskich regionach, z uwzględnieniem akumulacji kapitału fizycznego oraz ludzkiego (łączonego z latami nauki).

Pomiar produktywności często przeprowadzany jest w ujęciu względnym, relatywizującym stosunek wyników do nakładów danej jednostki względem granicy możliwości produkcyjnych dla ogółu badanych jednostek korzystających ze zbioru technologii wspólnej. Na takiej idei opiera się nieparametryczna metoda programowania liniowego DEA, która umożliwia oszacowanie granicy możliwości produkcyjnej i porównanie efektywności badanych podmiotów (tzw. DMU) z uwzględnieniem wielu nakładów i wielu wyników. Efektywność mierzona jest poprzez dystans dzielący badany obiekt do granicy możliwości wytwórczych. Wyrażana jest w postaci procentowej efektywności jednostek benchmarkingowych wyłonionych z badanej grupy obiektów jako odznaczających się najkorzystniejszą relacją wyników do nakładów. Modele DEA mogą być przy tym zorientowane na nakłady lub wyniki, zakładać stałe lub zmienne efekty skali, przyjmować charakter modeli radialnych lub też nieradialnych (Guzik, 2009).

Metoda DEA stanowi także podstawę do oceny zmian produktywności w czasie, pozwalając na obliczenie indeksu Malmquista oraz jego dekompozycję. Indeks Malmquista stanowi wskaźnik relacji wyniki-nakłady w różnych okresach odnoszonych do danej technologii. Jest średnią geometryczną relacji dwóch indeksów produktywności zakładających wykorzystanie technologii z dwóch okresów (Coelli, 1996; Tanase, Tidor, 2012). Spośród innych wskaźników pozwalających na ocenę zmian produktywności w czasie, do których należą również indeksy Törnqvista i Fishera, indeks Malmquista nie wymaga znajomości cen rynkowych nakładów i wyników, co prowadzi do jego częstszego zastosowania w praktyce (Ćwiąkała-Małys, Nowak, 2011: 273).

Jedna z możliwych opcji dekompozycji indeksu Malmquista przedstawiającego dynamikę produktywności wieloczynnikowej (tfpch), zgodnie z ideą R. Färe'a i in. (1994), zakłada wyodrębnienie wpływu zmian technologicznych (techch) oraz zmian efektywności technicznej (effch). Zmiany efektywności technicznej mogą być dodatkowo dekomponowane na czyste zmiany efektywności technicznej (pech) oraz zmiany efektywności skali (sech) (Coelli, 1996). Zmiana technologiczna łączona jest z wpływem postępu technologicznego, skutkującego zwiększeniem możliwości produkcyjnych i interpretowana jako wyraz innowacyjności. Zmiana czystej efektywności technicznej utożsamiana jest $\mathrm{z}$ efektem doganiania, a więc przybliżania się jednostki do danej granicy technologicznej i zmniejszaniem luki technologicznej do istniejącej technologii. Oznacza więc zdolność do unikania marnotrawstwa i wskazuje na poprawę praktyk zarządczych. Zmiana skali interpretowana jest jako odzwierciedlenie skutków zmiany popytu i możliwość działania w optymalnej skali (por. m.in. Chou, Shao, 2014; Bassem, 2014).

Pomiar poziomu oraz zmian produktywności dotyczy wyodrębnionej grupy obiektów, za które w analizach strukturalnych mogą być przyjęte sekcje działalności gospodarczej lub ich agregaty. Wielu autorów podkreśla wagę zmian produktywności poszczególnych rodzajów działalności dla ogólnogospodarczej dynamiki produktywności. Stanowisko takie zajmują m.in. D. Margaritis, R. Färe i Sh. Grosskopf (2007), wskazując, że w większości państw OECD największy wpływ na wzrost zagregowanej produktywności ma przemysł zaawansowany technologicznie oraz branże usługowe. Podobnie O. Badunenko i D. Romero-Ávila (2015) podkreślają rolę zmian efektywności poszczególnych sektorów dla wyników zagregowanych. Przedstawiane przez nich analizy gospodarki Hiszpanii zwracają uwagę na rolnictwo oraz przemysł jako sektory o największym oddziaływaniu na zmiany produktywności ogółem. Sektorowe stopy 
wzrostu produktywności są zasadniczym czynnikiem wyjaśniającym zarówno wzrost zagregowanej produktywności pracy, jak i produktywności wieloczynnikowej, również w ujęciu W.E. Diewerta (2015). Szeroko podkreślane znaczenie różnic międzybranżowych w stymulowaniu gospodarki uzasadnia więc poszukiwanie sektorów wiodących we współczesnej polskiej gospodarce.

\section{SKALA ORAZ KIERUNKI ZMIAN PRODUKCJI I STRUKTURY NAKŁADÓW W UKŁADZIE SEKCYJNYM}

Skala działalności gospodarczej realizowanej w poszczególnych sekcjach była w Polsce w analizowanym okresie znacznie zróżnicowana, zarówno w odniesieniu do wytwarzanej wartości, jak i nakładów czynników wytwórczych (tab. 1). Dominującym rodzajem działalności była w Polsce działalność przemysłowa oraz tradycyjne usługi (handel, transport). Pomimo iż zagregowany udział sektora usług (odpowiednio: 64\% produkcji, 52\% kapitału fizycznego, 81\% kapitału ludzkiego i 47\% pracy prostej) wskazuje na etap tercjarny rozwoju gospodarki kraju, to należy mieć na uwadze wczesny charakter tego procesu. Obserwacja ta jest zgodna z badaniami B. Fury (2017) ukierunkowanymi na identyfikację sektorów kluczowych w polskiej gospodarce, które dowodzą znaczącej roli usług, ale z wciąż dostrzegalną rolą przemysłu i usług.

Tab. 1. Statystyki opisowe wyników i nakładów produkcyjnych w sekcjach działalności gospodarczej w Polsce w latach 2008-2016

\begin{tabular}{|c|c|c|c|c|c|c|c|c|}
\hline \multirow[t]{2}{*}{ Sekcje } & \multicolumn{2}{|c|}{$\begin{array}{c}\text { Produkcja } \\
\text { (realna wartość } \\
\text { dodana brutto,w mln } \\
\text { zł, w 2010) }\end{array}$} & \multicolumn{2}{|c|}{$\begin{array}{l}\text { Kapitał fizyczny } \\
\text { (realna wartość } \\
\text { zużycia środków } \\
\text { trwałych, w mln zł, } \\
\text { w 2010) }\end{array}$} & \multicolumn{2}{|c|}{$\begin{array}{c}\text { Kapitał ludzki } \\
\text { (liczba zatrudnionych } \\
\text { z wyższym } \\
\text { wykształceniem, } \\
\text { w tys.) }\end{array}$} & \multicolumn{2}{|c|}{$\begin{array}{c}\text { Praca prosta } \\
\text { (liczba zatrudnionych } \\
\text { bez wyższego } \\
\text { wykształcenia, w tys.) }\end{array}$} \\
\hline & $\mathrm{a}$ & V & $\mathrm{a}$ & $\mathrm{V}$ & $a$ & $\mathrm{~V}$ & $a$ & $\mathrm{~V}$ \\
\hline $\mathrm{AB}$ & 68764,1 & $4 \%$ & 16315,9 & $6 \%$ & 142,8 & $17 \%$ & 2032,5 & $9 \%$ \\
\hline $\mathrm{C}$ & 249392,8 & $14 \%$ & 39093,9 & $11 \%$ & 505,3 & $17 \%$ & 2513,3 & $5 \%$ \\
\hline DEF & 173977,9 & $9 \%$ & 30664,0 & $11 \%$ & 247,0 & $17 \%$ & 1287,7 & $6 \%$ \\
\hline $\mathrm{G}$ & 245362,4 & $5 \%$ & 10941,1 & $12 \%$ & 524,0 & $15 \%$ & 1773,3 & $5 \%$ \\
\hline $\mathrm{H}$ & 79125,7 & $10 \%$ & 21386,8 & $13 \%$ & 138,9 & $20 \%$ & 756,4 & $2 \%$ \\
\hline I & 15521,4 & $10 \%$ & 1095,4 & $12 \%$ & 55,7 & $27 \%$ & 281,6 & $4 \%$ \\
\hline $\mathrm{J}$ & 58660,1 & $18 \%$ & 12056,4 & $16 \%$ & 227,4 & $16 \%$ & 101,1 & $9 \%$ \\
\hline $\mathrm{K}$ & 60830,2 & $15 \%$ & 6183,1 & $10 \%$ & 251,9 & $12 \%$ & 122,8 & $12 \%$ \\
\hline $\mathrm{L}$ & 70309,0 & $7 \%$ & 15883,4 & $6 \%$ & 57,5 & $18 \%$ & 99,6 & $7 \%$ \\
\hline M & 72703,4 & $11 \%$ & 4815,1 & $15 \%$ & 359,8 & $17 \%$ & 149,6 & $4 \%$ \\
\hline $\mathrm{N}$ & 27649,7 & $21 \%$ & 1780,2 & $17 \%$ & 73,4 & $19 \%$ & 342,0 & $5 \%$ \\
\hline OU & 76212,1 & $2 \%$ & 9061,4 & $6 \%$ & 599,6 & $12 \%$ & 439,1 & $9 \%$ \\
\hline$P$ & 65426,9 & $2 \%$ & 5802,7 & $17 \%$ & 882,7 & $4 \%$ & 325,8 & $5 \%$ \\
\hline Q & 59045,9 & $12 \%$ & 3609,0 & $17 \%$ & 394,8 & $18 \%$ & 516,4 & $7 \%$ \\
\hline $\mathrm{R}$ & 10586,8 & $9 \%$ & 1396,0 & $22 \%$ & 93,4 & $12 \%$ & 107,4 & $7 \%$ \\
\hline ST & 21008,3 & $13 \%$ & 333,9 & $22 \%$ & 57,1 & $16 \%$ & 212,3 & $7 \%$ \\
\hline
\end{tabular}

a - wartość średniej arytmetycznej dla zmiennej w latach 2008-2016; V - współczynnik zmienności dla zmiennej w latach 2008-2016

Źródło: obliczenia własne na podstawie danych Eurostatu (2018) 
Waga poszczególnych sekcji była przy tym odmienna w odniesieniu do produkcji i nakładów: kapitału fizycznego, ludzkiego i pracy prostej. W zakresie produkcji największe było znaczenie przetwórstwa przemysłowego (C) oraz handlu (G), a kolejno działalności związanej z gospodarką komunalną i budownictwa (DEF). W odniesieniu do zaangażowania kapitału fizycznego również dominowało przetwórstwo przemysłowe (C), jednak następne miejsca przypadły w udziale gospodarce komunalnej i budownictwu (DEF) oraz działalności transportowej (H). Największa część kapitału ludzkiego zaabsorbowana była w edukacji (P), administracji (OU) oraz handlu (G). Przetwórstwo przemysłowe $(\mathrm{C})$, rolnictwo i górnictwo $(\mathrm{AB})$ oraz handel $(\mathrm{G})$ miały natomiast największe znaczenie w zatrudnieniu pracy prostej. Ogólne zestawienie charakterystyk strukturalnych polskiej gospodarki w tych czterech wymiarach sugeruje istnienie zasadniczych różnic w zakresie produktywności zarówno ogólnej, jak i czynnikowej poszczególnych sekcji. Specyfika branżowa wyraźnie determinuje bowiem relacje wykorzystania poszczególnych nakładów, określające stopień kapitałochłonności i pracochłonności produkcji. Sektor usług jako całość jest przy tym dziedziną w relatywnie największym stopniu absorbującą kapitał ludzki, co wskazuje na jego wysoką wiedzochłonność.

Zaobserwować można ponadto różnice między sekcjami w kształtowaniu się relacji produkcyjnych i czynnikowych w czasie. Największą zmienność w analizowanym okresie (tab. 1) w zakresie produkcji odnotować można w usługach wspierających (N) oraz informacyjno-komunikacyjnych (J), w zakresie kapitału fizycznego: w działalności kulturalnej (R) i pozostałych usługach (ST), w zakresie kapitału ludzkiego: w zakwaterowaniu i gastronomii (I), a w zakresie pracy prostej: w finansach (K).

Tab. 2. Dynamika produkcji i nakładów produkcyjnych pomiędzy 2008 a 2016 r. w sekcjach działalności gospodarczej w Polsce

\begin{tabular}{|l|c|c|c|c|}
\hline \multicolumn{1}{|c|}{ Sekcje } & Produkcja & Kapitał fizyczny & Kapitał ludzki & Praca prosta \\
\hline AB & $90 \%$ & $115 \%$ & $163 \%$ & $75 \%$ \\
\hline C & $148 \%$ & $132 \%$ & $160 \%$ & $92 \%$ \\
\hline DEF & $126 \%$ & $129 \%$ & $162 \%$ & $89 \%$ \\
\hline G & $120 \%$ & $133 \%$ & $152 \%$ & $91 \%$ \\
\hline H & $122 \%$ & $138 \%$ & $181 \%$ & $98 \%$ \\
\hline I & $125 \%$ & $139 \%$ & $228 \%$ & $109 \%$ \\
\hline J & $165 \%$ & $155 \%$ & $153 \%$ & $75 \%$ \\
\hline K & $133 \%$ & $123 \%$ & $142 \%$ & $74 \%$ \\
\hline L & $121 \%$ & $117 \%$ & $156 \%$ & $94 \%$ \\
\hline M & $133 \%$ & $156 \%$ & $168 \%$ & $99 \%$ \\
\hline N & $188 \%$ & $150 \%$ & $196 \%$ & $106 \%$ \\
\hline OU & $102 \%$ & $122 \%$ & $142 \%$ & $79 \%$ \\
\hline P & $102 \%$ & $165 \%$ & $107 \%$ & $86 \%$ \\
\hline Q & $140 \%$ & $161 \%$ & $176 \%$ & $81 \%$ \\
\hline R & $89 \%$ & $189 \%$ & $131 \%$ & $94 \%$ \\
\hline ST & $135 \%$ & $188 \%$ & $158 \%$ & $125 \%$ \\
\hline ogółem & $127 \%$ & $132 \%$ & $147 \%$ & $88 \%$ \\
\hline
\end{tabular}

Źródło: obliczenia własne na podstawie danych Eurostatu (2018)

Zmiany te związane były ze wzrostem wartości produkcji pomiędzy 2008 a 2016 rokiem w większości sekcji, w tym przede wszystkim w usługach wspierających (N) 
oraz informacyjno-komunikacyjnych (J). Spadki dotyczyły wyłącznie usług kulturalnych (R) oraz rolnictwa i górnictwa (AB). We wszystkich sekcjach odnotowano wzrost wykorzystania kapitału fizycznego, który największy był w usługach kulturalnych (R) oraz pozostałych (ST), a także kapitału ludzkiego - z dominującą dynamiką w zakwaterowaniu i gastronomii (I). Zaangażowanie pracy prostej zmniejszyło się natomiast w odniesieniu do większości sekcji, w największym stopniu w finansach (K). Wzrost zatrudnienia osób o co najwyżej średnim wykształceniu miał miejsce jedynie w usługach pozostałych (ST), hotelarsko-gastronomicznych (I) oraz wspierających (N) (tab. 2).

Pomimo różnic międzysekcyjnych w dynamice produkcji i poszczególnych nakładów, dla całej polskiej gospodarki w latach 2008-2016 (ryc. 1) charakterystyczny był stały wzrost poziomu produkcji, także zaangażowania kapitału ludzkiego i fizycznego. Wyraźnie ograniczona została natomiast absorpcja gospodarcza pracy prostej. Wśród czynników wytwórczych relatywnie największy wzrost dotyczył kapitału ludzkiego (tab. 2). Tendencje te potwierdzają stopniowy rozwój modelu gospodarki opartej na wiedzy w polskiej rzeczywistości, w którym to procesie zasadniczą rolę pełnią usługi.

\section{ZMIANY PRODUKTYWNOŚCI SEKCYJNEJ I ICH DEKOMPOZYCJA}

Zastosowanie modelu DEA-CRS pozwala na zestawienie ogólnej produktywności poszczególnych sekcji w analizowanym okresie (tab. 3). Korzystając ze wspólnej technologii, w pełni efektywnie wykorzystywały dostępne nakłady do maksymalizowania produkcji sekcje: handel (G), obsługa nieruchomości (L), usługi profesjonalne (M) oraz pozostałe (ST). Pod koniec analizowanego okresu pełną efektywnością cechowały się również informacja i komunikacja (J) oraz finanse (K). Najmniej efektywna była działalność kulturalna (R), która ponadto wykazywała się spadkiem efektywności w czasie. Niekorzystne były również relacje produkcji do nakładów w administracji (OU), a także zakwaterowaniu i gastronomii (I) oraz rolnictwie i górnictwie (AB).

Tab. 3. Efektywność sekcji działalności gospodarczej w Polsce (DEA-CRS)

\begin{tabular}{|l|l|l|l|l|l|l|l|l|l|c|}
\hline Sekcje & 2008 & 2009 & 2010 & 2011 & 2012 & 2013 & 2014 & 2015 & 2016 & $\begin{array}{c}\text { Średnia } \\
2008-2016\end{array}$ \\
\hline AB & 0,765 & 0,730 & 0,674 & 0,656 & 0,615 & 0,639 & 0,579 & 0,618 & 0,561 & 0,649 \\
\hline C & 0,685 & 0,689 & 0,766 & 0,792 & 0,791 & 0,766 & 0,795 & 0,859 & 0,790 & 0,770 \\
\hline DEF & 0,857 & 0,910 & 0,929 & 1,000 & 0,954 & 0,871 & 0,872 & 0,943 & 0,838 & 0,908 \\
\hline G & 1,000 & 1,000 & 1,000 & 1,000 & 1,000 & 1,000 & 1,000 & 1,000 & 1,000 & 1,000 \\
\hline H & 0,706 & 0,621 & 0,632 & 0,727 & 0,706 & 0,662 & 0,642 & 0,658 & 0,609 & 0,663 \\
\hline I & 0,712 & 0,668 & 0,627 & 0,634 & 0,546 & 0,560 & 0,601 & 0,631 & 0,543 & 0,614 \\
\hline J & 0,771 & 0,864 & 0,875 & 0,871 & 0,868 & 0,869 & 0,898 & 1,000 & 1,000 & 0,891 \\
\hline K & 0,967 & 0,878 & 0,942 & 1,000 & 0,835 & 0,930 & 1,000 & 1,000 & 1,000 & 0,950 \\
\hline L & 1,000 & 1,000 & 1,000 & 1,000 & 1,000 & 1,000 & 1,000 & 1,000 & 1,000 & 1,000 \\
\hline M & 1,000 & 1,000 & 1,000 & 1,000 & 1,000 & 1,000 & 1,000 & 1,000 & 1,000 & 1,000 \\
\hline N & 0,724 & 0,594 & 0,669 & 0,750 & 0,827 & 0,857 & 0,771 & 0,918 & 0,890 & 0,778 \\
\hline OU & 0,545 & 0,564 & 0,570 & 0,563 & 0,552 & 0,537 & 0,545 & 0,507 & 0,511 & 0,544 \\
\hline P & 0,736 & 0,748 & 0,724 & 0,709 & 0,674 & 0,627 & 0,608 & 0,584 & 0,585 & 0,666 \\
\hline Q & 0,594 & 0,626 & 0,716 & 0,731 & 0,666 & 0,672 & 0,696 & 0,697 & 0,743 & 0,682 \\
\hline R & 0,525 & 0,524 & 0,497 & 0,496 & 0,466 & 0,368 & 0,354 & 0,345 & 0,360 & 0,437 \\
\hline ST & 1,000 & 1,000 & 1,000 & 1,000 & 1,000 & 1,000 & 1,000 & 1,000 & 1,000 & 1,000 \\
\hline
\end{tabular}

Źródło: obliczenia własne na podstawie danych Eurostatu (2018) 


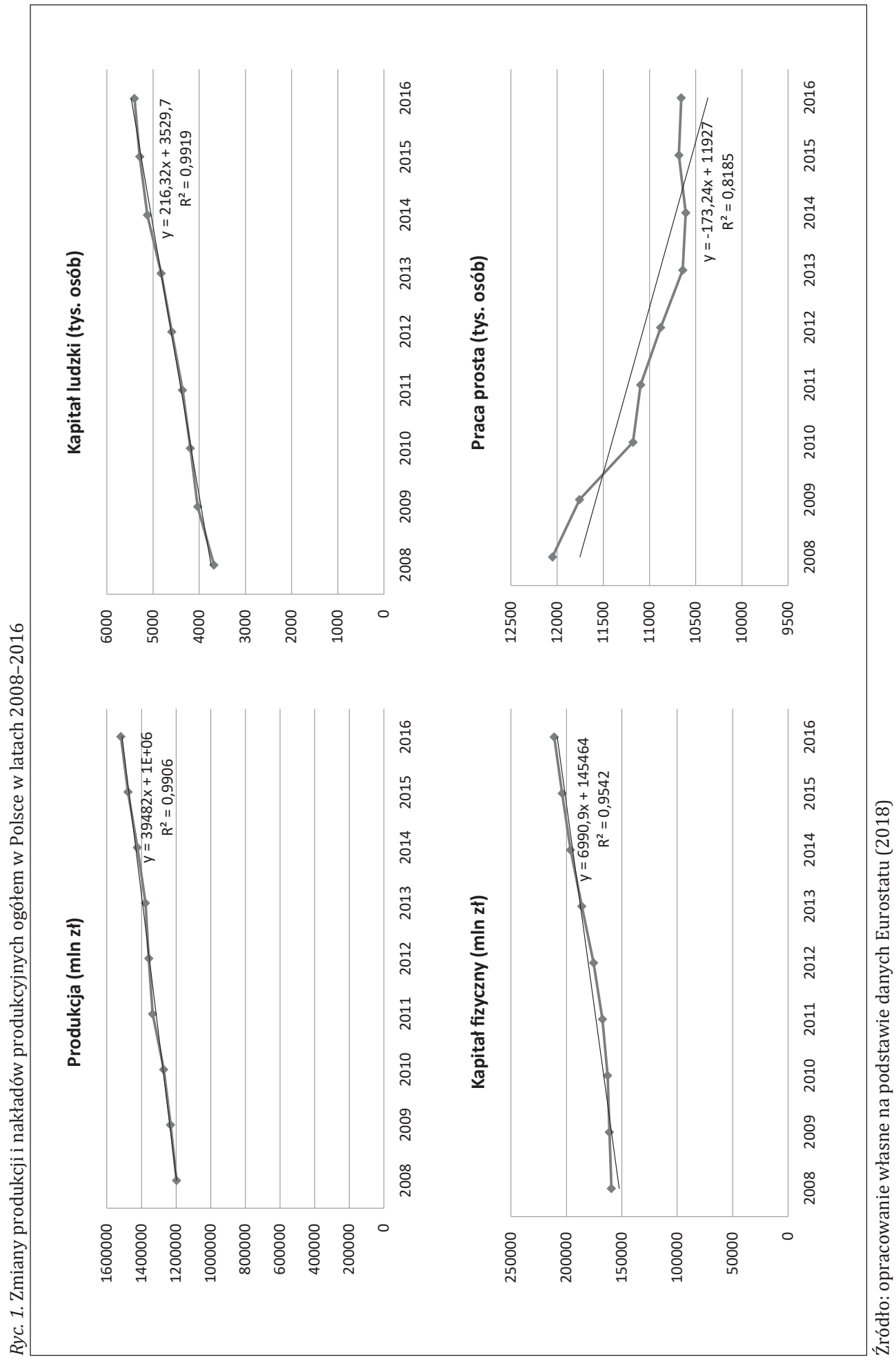


W latach 2008-2016 w Polsce odnotowano przeciętny spadek ogólnej produktywności mierzony indeksem Malmquista dla sekcji (tab. 4). Spośród 16 sekcji aż 11 odnotowało ujemną dynamikę produktywności. Okres kryzysowy charakteryzujący się ograniczeniem popytowym limitował dynamikę wzrostu produkcji. Jednocześnie zaburzenia popytowe łączyły się z kumulacją większości zasobów czynników wytwórczych, skutkując obniżeniem efektywności ich wykorzystania.

Dekompozycja zmian produktywności (tab. 4) wskazuje, że negatywne efekty dotyczyły zarówno oddziaływania postępu technologicznego, odzwierciedlonego obniżeniem granicy możliwości wytwórczych, jak i efektywności technicznej, uwidocznionej oddalaniem się od granicy możliwości wytwórczych. Zmniejszenie możliwości wytwórczych dotyczyło aż 13 spośród 16 sekcji, natomiast niższą efektywność techniczną zanotowano w siedmiu sekcjach, przy czym dodatkowe cztery utrzymały niezmieniony jej poziom. Średni poziom wskaźników obniżył się w obu wymiarach. Ponadto zmiany efektywności technicznej warunkowane były spadkiem czystej efektywności realizowanej działalności, których nie był w stanie zrekompensować obserwowany wzrost efektywności skali funkcjonowania. Negatywny wpływ zjawisk kryzysowych uwidaczniał się więc w nieracjonalnym ekonomicznie wykorzystaniu zasobów, niewątpliwie wyhamowując dynamikę gospodarki.

Tab. 4. Dynamika produktywności w sekcjach działalności gospodarczej w Polsce w latach 2008-2016 i jej dekompozycja

\begin{tabular}{|l|l|l|l|l|l|}
\hline Sekcje & effch & techch & pech & sech & tfpch \\
\hline AB & 0,962 & 0,984 & 0,961 & 1,001 & 0,947 \\
\hline C & 1,018 & 0,981 & 1,010 & 1,008 & 0,999 \\
\hline DEF & 0,997 & 0,985 & 1,000 & 0,997 & 0,982 \\
\hline G & 1,000 & 0,994 & 1,000 & 1,000 & 0,994 \\
\hline H & 0,982 & 0,987 & 0,987 & 0,995 & 0,969 \\
\hline I & 0,967 & 0,970 & 0,941 & 1,028 & 0,938 \\
\hline J & 1,033 & 1,041 & 1,020 & 1,013 & 1,075 \\
\hline K & 1,004 & 1,023 & 1,003 & 1,001 & 1,028 \\
\hline L & 1,000 & 0,991 & 1,000 & 1,000 & 0,991 \\
\hline M & 1,000 & 1,003 & 1,000 & 1,000 & 1,003 \\
\hline N & 1,026 & 0,975 & 1,014 & 1,012 & 1,001 \\
\hline OU & 0,992 & 0,991 & 0,982 & 1,010 & 0,983 \\
\hline P & 0,972 & 0,991 & 0,972 & 1,000 & 0,963 \\
\hline Q & 1,029 & 0,996 & 1,013 & 1,015 & 1,024 \\
\hline R & 0,954 & 0,994 & 1,000 & 0,954 & 0,948 \\
\hline ST & 1,000 & 0,984 & 1,000 & 1,000 & 0,984 \\
\hline średnia & 0,996 & 0,993 & 0,994 & 1,002 & 0,989 \\
\hline
\end{tabular}

effch - zmiana efektywności technicznej; techch - zmiana technologiczna; pech - zmiana czystej efektywności technicznej; sech - zmiana efektywności skali; tfpch - zmiana ogólnej produktywności

Źródło: obliczenia własne na podstawie danych Eurostatu (2018)

Pomimo negatywnych zmian ogólnogospodarczych pięć sekcji odnotowało przyrost produktywności, który stanowił o akceleracji wzrostu. Najwyższą dynamiką produktywności wieloczynnikowej charakteryzowała się sekcja informacyjno-komunikacyjna (J), która tym samym wykazuje cechy podstawowej motorycznej jednostki 
wzrostu w polskiej gospodarce. Korzystne zmiany dotyczyły także sekcji finansowo-ubezpieczeniowej (K), która wobec zjawisk kryzysu finansowego w szczególności poddana została głębokiej restrukturyzacji. Wysoki wskaźnik zmian produktywności cechował także ochronę zdrowia (Q), wskazując na rosnące znaczenie tych usług dla polskiego społeczeństwa. Nieznaczną poprawę efektywności odnotowano także w usługach profesjonalnych (M) oraz wspomagających (N), co potwierdza tendencje do dynamizacji rozwoju sfery usług biznesowych. Wszystkie te sekcje mają przy tym charakter usługowy, a dodatnie wskaźniki zmian produktywności w okresie kryzysowym dowodzą siły przekształceń w kierunku gospodarki usługowej bazującej na szerszym wykorzystaniu wiedzy.

Podkreślić należy, że spośród wszystkich sekcji jedynie informacja i komunikacja (J), finanse i ubezpieczenia (K) oraz usługi profesjonalne (M) doświadczyły postępu technologicznego zwiększającego możliwości wytwórcze. Innowacyjność współwystępowała tu z poprawą sprawności zarządczej, skutkując wzrostem produktywności. W tych dziedzinach należy więc poszukiwać biegunów rozwojowych dających szansę na szerszą dyfuzję wiedzy i zmniejszenie dystansu polskiej gospodarki do państw najwyżej rozwiniętych.

Z drugiej strony największe spadki produktywności odnotowano w sekcji hotelarsko-gastronomicznej (I), która ma charakter tradycyjnej działalności usługowej opartej na pracochłonnych metodach wytwarzania i jednocześnie relatywnie wysokiej elastyczności dochodowej. Ponadto znaczną ujemną dynamiką cechowało się rolnictwo i górnictwo (AB), co może się łączyć ze schyłkowym charakterem tego typu działalności. Porównywalne spadki produktywności dotyczyły także działalności kulturalno-rozrywkowej (R), która okazała się wrażliwa na kryzysowe ograniczenia dochodowe.

Sekcje o największych spadkach produktywności były jednocześnie dziedzinami, które doświadczyły najgłębszych ograniczeń efektywności technicznej. Ograniczenia popytowe, zarówno indukowane zjawiskami kryzysowymi, jak i wynikające ze schyłkowego charakteru działalności, skutkowały w tych sekcjach nieefektywnym utrzymywaniem zasobów czynników wytwórczych. 0 ile sytuacja taka z pewnością łagodzi zaburzenia społeczne, o tyle z punktu widzenia racjonalności ekonomicznej może być uzasadniona jedynie w przypadku łagodzenia bieżących wahań koniunkturalnych i utrzymywania zasobów w celu dostosowania produkcji do wzrastającego zapotrzebowania w okresach poprawy koniunktury. Takie przesłanki wydają się wątpliwe w odniesieniu do działalności rolniczej i górnictwa, wskazując na strukturalne słabości polskiej gospodarki związane z nadmierną skalą tego rodzaju działalności.

\section{DYNAMIKA PRODUKTYWNOŚCI CZYNNIKOWEJ W SEKCJACH DZIAŁALNOŚCI GOSPODARCZEJ}

Specyfika poszczególnych rodzajów działalności i ich modernizacji determinuje również tendencje w zakresie zmian produktywności jednoczynnikowej. Zestawienie średniej dla sekcji dynamiki produktywności poszczególnych czynników wytwórczych (tab. 5-7) pozwala stwierdzić, że jedynie w odniesieniu do wykorzystania pracy prostej odnotowano korzystne zmiany. Najgłębsze były spadki produktywności kapitału ludzkiego, a jedynie nieco mniejsze kapitału fizycznego. Zmiany te należy jednak interpretować łącznie ze względu na komplementarny charakter zaangażowania 
czynników wytwórczych. Wynikające z dostępu do zasobów kapitału fizycznego techniczne uzbrojenie pracy czy też dostęp do wiedzy warunkowany jej dyfuzją od osób wyposażonych w kapitał ludzki stanowią zasadnicze czynniki zwiększające produktywność pracy prostej. Podobnie efektywność produkcyjna kapitału ludzkiego wspomagana jest dostępem do wyposażenia technicznego czy prac wspierających. Zmiany produktywności kapitału fizycznego nie byłyby zaś możliwe bez czynnika ludzkiego. Tym samym wysoka dynamika produktywności pracy prostej może wynikać z korzystnych zmian struktury zaangażowania czynników wytwórczych, określonych wzrostem zaangażowania wiedzy ucieleśnionej zarówno w człowieku, jak i w wyposażeniu technicznym. Zwrot w kierunku gospodarki wiedzochłonnej w Polsce ma więc swoje efekty w postaci rosnącej produktywności pracy prostej. Jednocześnie wyniki te mogą wskazywać na skutki zjawisk kryzysowych w postaci ograniczenia zatrudnienia głównie pracowników niewykwalifikowanych, co prowadzi do wzrostu produktywności pracy prostej.

Współzależności pomiędzy produktywnością poszczególnych czynników wytwórczych podkreślają również wyniki dekompozycji indeksu Malmquista na postęp technologiczny i zmiany efektywności technicznej (tab. 5-7). Zarówno w odniesieniu do kapitału fizycznego, jak i - choć w mniejszym stopniu - do kapitału ludzkiego zaobserwowano poprawę efektywności technicznej przy negatywnym przesunięciu możliwości wytwórczych. Poprawa efektywności technicznej wynikała przy tym z poprawy efektywności skali. Dekompozycja zmian produktywności pracy prostej wykazała natomiast odwrotne relacje. W tym przypadku odnotowano postęp technologiczny zwiększający możliwości produkcyjne i nieznaczne ograniczenie efektywności technicznej, w tym pogorszenie efektywności skali przy nieznacznej poprawie czystej efektywności technicznej. Tym samym relacje te podkreślają, że zmiany produktywności w zasadniczym stopniu warunkowane są zmianami proporcji zaangażowania czynników wytwórczych w kierunku czynników wiedzochłonnych - kapitału fizycznego i ludzkiego. Otrzymane wyniki sugerują jednocześnie, że rozwój w kierunku gospodarki opartej na wiedzy ma w Polsce głównie charakter ekstensywny, związany z większym udziałem zasobów opartych na wiedzy, które jednak obecnie stosunkowo nieznacznie przesuwają granicę możliwości produkcyjnych. Relatywnie niska intensywność wykorzystania wiedzy wskazuje na pozycję Polski jako państwa „doganiającego" pozycję liderów.

Pomimo ujemnej przeciętnej dynamiki produktywności kapitału fizycznego (tab. 5) poszczególne sekcje wykazują zróżnicowane zmiany. Pięć sekcji odnotowało wzrost produktywności kapitału fizycznego, spośród których najkorzystniejsze wyniki dotyczyły usług wspierających (N), będących działalnością w znacznym stopniu opierającą się na pracy ludzkiej. Produktywność kapitału fizycznego wzrosła także w przetwórstwie przemysłowym (C), o typowo dużym udziale kapitału fizycznego, jak również w sekcji informacyjno-komunikacyjnej (J), finansowo-ubezpieczeniowej (K) oraz w obsłudze nieruchomości (L). W tych wszystkich sekcjach wzrost produktywności kapitału fizycznego może wynikać ze zmiany proporcji jego wykorzystania względem czynnika ludzkiego. Najgłębsze spadki produktywności kapitału fizycznego obecne były natomiast w działalności rozrywkowo-kulturalnej (R) oraz edukacji (P), które jednocześnie były jedynymi sekcjami doświadczającymi spadku efektywności technicznej nakładającym się na obniżenie granicy możliwości wytwórczych. 
Tab. 5. Dynamika produktywności kapitału fizycznego w sekcjach działalności gospodarczej w Polsce w latach 2008-2016 i jej dekompozycja

\begin{tabular}{|l|l|l|l|l|l|}
\hline \multicolumn{1}{|c|}{ Sekcje } & effch & techch & pech & sech & tfpch \\
\hline AB & 1,011 & 0,960 & 0,962 & 1,051 & 0,970 \\
\hline C & 1,057 & 0,960 & 1,010 & 1,046 & 1,014 \\
\hline DEF & 1,039 & 0,960 & 0,995 & 1,045 & 0,997 \\
\hline G & 1,030 & 0,960 & 1,000 & 1,030 & 0,988 \\
\hline H & 1,026 & 0,960 & 0,995 & 1,031 & 0,985 \\
\hline I & 1,028 & 0,960 & 1,001 & 1,028 & 0,987 \\
\hline J & 1,050 & 0,960 & 1,034 & 1,015 & 1,007 \\
\hline K & 1,052 & 0,960 & 1,021 & 1,031 & 1,010 \\
\hline L & 1,046 & 0,960 & 0,998 & 1,048 & 1,004 \\
\hline M & 1,021 & 0,960 & 0,994 & 1,027 & 0,980 \\
\hline N & 1,071 & 0,960 & 1,045 & 1,025 & 1,028 \\
\hline OU & 1,019 & 0,960 & 0,989 & 1,030 & 0,978 \\
\hline P & 0,982 & 0,960 & 0,957 & 1,026 & 0,942 \\
\hline Q & 1,024 & 0,960 & 0,998 & 1,025 & 0,982 \\
\hline R & 0,948 & 0,960 & 0,935 & 1,014 & 0,910 \\
\hline ST & 1,000 & 0,960 & 1,000 & 1,000 & 0,960 \\
\hline Średnia & 1,025 & 0,960 & 0,996 & 1,029 & 0,984 \\
\hline
\end{tabular}

effch - zmiana efektywności technicznej; techch - zmiana technologiczna; pech - zmiana czystej efektywności technicznej; sech - zmiana efektywności skali; tfpch - zmiana ogólnej produktywności

Źródło: obliczenia własne na podstawie danych Eurostatu (2018)

Tab. 6. Dynamika produktywności pracy prostej w sekcjach działalności gospodarczej w Polsce w latach 2008-2016 i jej dekompozycja

\begin{tabular}{|l|c|c|c|c|c|}
\hline Sekcje & effch & techch & pech & sech & tfpch \\
\hline AB & 0,982 & 1,042 & 0,964 & 1,018 & 1,023 \\
\hline C & 1,019 & 1,042 & 1,010 & 1,009 & 1,061 \\
\hline DEF & 1,003 & 1,042 & 1,007 & 0,996 & 1,045 \\
\hline G & 0,995 & 1,042 & 1,000 & 0,995 & 1,036 \\
\hline H & 0,987 & 1,042 & 0,995 & 0,992 & 1,028 \\
\hline I & 0,976 & 1,042 & 0,995 & 0,981 & 1,017 \\
\hline J & 1,060 & 1,042 & 1,042 & 1,017 & 1,104 \\
\hline K & 1,034 & 1,042 & 1,015 & 1,019 & 1,077 \\
\hline L & 0,991 & 1,042 & 0,998 & 0,993 & 1,033 \\
\hline M & 0,996 & 1,042 & 1,007 & 0,989 & 1,038 \\
\hline N & 1,031 & 1,042 & 1,047 & 0,984 & 1,073 \\
\hline OU & 0,991 & 1,042 & 0,985 & 1,006 & 1,032 \\
\hline P & 0,981 & 1,042 & 0,980 & 1,001 & 1,021 \\
\hline Q & 1,029 & 1,042 & 1,024 & 1,004 & 1,071 \\
\hline R & 0,953 & 1,042 & 0,960 & 0,993 & 0,993 \\
\hline ST & 0,969 & 1,042 & 1,001 & 0,968 & 1,009 \\
\hline średnia & 0,999 & 1,042 & 1,002 & 0,998 & 1,041 \\
\hline
\end{tabular}

effch - zmiana efektywności technicznej; techch - zmiana technologiczna; pech - zmiana czystej efektywności technicznej; sech - zmiana efektywności skali; tfpch - zmiana ogólnej produktywności

Źródło: obliczenia własne na podstawie danych Eurostatu (2018) 
Wskazany wcześniej wzrost średniego poziomu produktywności pracy prostej (tab. 6) wynikał z obecności tendencji wzrostowych aż w 15 sekcjach. Największą poprawę wyników odnotowano w działalności informacyjno-komunikacyjnej (J). Na kolejnych pozycjach znalazły się sekcje: finansowo-ubezpieczeniowa (K), usługi wspierające $(\mathrm{N})$ oraz ochrona zdrowia (Q). Są to sekcje, które charakteryzowały się również największą dynamiką produktywności wieloczynnikowej, a więc należy poszukiwać tożsamych źródeł dynamiki produktywności ogólnej i produktywności pracy. Wydaje się, że wzrost wyposażenia kapitałowego jest tutaj najlepszym wyjaśnieniem. Wskazane sekcje odnotowały jednocześnie największy wzrost efektywności technicznej wykorzystania pracy prostej. Należy przy tym zauważyć, że dodatnie przesunięcia w kierunku granicy możliwości wytwórczych dotyczyły jeszcze wyłącznie przetwórstwa przemysłowego (C) oraz gospodarki komunalnej i budownictwa (DEF). Wzmocniły one pozytywne efekty postępu technologicznego dla pracy prostej wspólne dla wszystkich sekcji. Jedyny spadek produktywności pracy prostej zaobserwowano natomiast w działalności rozrywkowo-kulturalnej (R), który wynikał z głębokiego pogorszenia efektywności technicznej.

Tab. 7. Dynamika produktywności kapitału ludzkiego w sekcjach działalności gospodarczej w Polsce w latach 2008-2016 i jej dekompozycja

\begin{tabular}{|l|l|l|l|l|l|}
\hline \multicolumn{1}{|c|}{ Sekcje } & effch & techch & pech & sech & tfpch \\
\hline AB & 0,959 & 0,968 & 0,959 & 1,000 & 0,929 \\
\hline C & 1,023 & 0,968 & 1,010 & 1,012 & 0,990 \\
\hline DEF & 1,001 & 0,968 & 1,000 & 1,001 & 0,969 \\
\hline G & 1,003 & 0,968 & 0,991 & 1,012 & 0,971 \\
\hline H & 0,983 & 0,968 & 0,988 & 0,995 & 0,952 \\
\hline I & 0,957 & 0,968 & 0,821 & 1,166 & 0,927 \\
\hline J & 1,042 & 0,968 & 1,039 & 1,003 & 1,009 \\
\hline K & 1,024 & 0,968 & 1,016 & 1,008 & 0,992 \\
\hline L & 1,000 & 0,968 & 1,000 & 1,000 & 0,968 \\
\hline M & 1,002 & 0,968 & 0,999 & 1,004 & 0,971 \\
\hline N & 1,027 & 0,968 & 1,043 & 0,985 & 0,995 \\
\hline OU & 0,991 & 0,968 & 0,964 & 1,028 & 0,960 \\
\hline P & 1,026 & 0,968 & 0,964 & 1,064 & 0,994 \\
\hline Q & 1,003 & 0,968 & 1,000 & 1,003 & 0,972 \\
\hline R & 0,983 & 0,968 & 0,972 & 1,011 & 0,952 \\
\hline ST & 1,013 & 0,968 & 1,013 & 1,000 & 0,981 \\
\hline średnia & 1,002 & 0,968 & 0,985 & 1,017 & 0,970 \\
\hline
\end{tabular}

effch - zmiana efektywności technicznej; techch - zmiana technologiczna; pech - zmiana czystej efektywności technicznej; sech - zmiana efektywności skali; tfpch - zmiana ogólnej produktywności

Źródło: obliczenia własne na podstawie danych Eurostatu (2018)

Ujemny wynik średniej dla sekcji dynamiki produktywności kapitału ludzkiego (tab. 7) wynikał z pogorszenia tych relacji dla aż 15 rodzajów działalności. Jedyny wyjątek stanowiła sekcja J: informacja i komunikacja. W sekcji tej negatywny efekt przesunięcia granicy możliwości wytwórczych został zrekompensowany znaczną poprawą efektywności technicznej. Efektywność techniczna uległa poprawie jeszcze w dziewięciu innych sekcjach, w tym w szczególności w usługach wspierających (N) 
oraz edukacji (P), jednak w żadnych z tych przypadków efekt ten nie przeważył nad negatywnym efektem technologicznym. Największe spadki produktywności kapitału ludzkiego dotyczyły natomiast usług hotelarsko-gastronomicznych (I) oraz rolnictwa i górnictwa $(\mathrm{AB})$. Dominacja negatywnych efektów w zakresie produktywności kapitału ludzkiego wiąże się z coraz większą skalą zaangażowania gospodarczego tego czynnika wytwórczego. Stosowanie tego zasobu w Polsce ma przy tym głównie charakter ekstensywny, uniemożliwiający pełne wykorzystanie potencjalnych korzystnych efektów postępu technologicznego.

\section{ZAKOŃCZENIE}

Przeprowadzone analizy zmiany produktywności według rodzajów działalności gospodarczej w Polsce pozwalają wskazać na pogorszenie się tych relacji w okresie od ujawnienia się ogólnoświatowych zjawisk kryzysowych. Źródła negatywnej dynamiki produktywności identyfikowane są zarówno w komponencie efektywności technicznej, jak i postępu technologicznego. Oznacza to pogorszenie wyników zarządczych związanych z efektem zbliżania się jednostek nieefektywnych do granicy technologicznej, jak i problemy związane z działalnością jednostek wzorcowych, wyznaczających granicę możliwości wytwórczych. Dodatni wpływ miał wyłącznie komponent związany z efektywnością skali funkcjonowania. Wnioskować więc można, że pomimo utrzymania dodatniej dynamiki produkcji w Polsce negatywne skutki zjawisk kryzysowych były również obecne w krajowej gospodarce. Związane one były jednak z pogorszeniem relacji produktywnościowych i nakładały się na wewnętrzne przekształcenia strukturalne w układzie zarówno sekcyjnym, jak i czynnikowym.

Zestawienie wyników dla poszczególnych sekcji pozwala zidentyfikować te rodzaje działalności, które - pomimo ogólnie negatywnych zmian produktywności - odnotowały jej dodatnią dynamikę, dodatkowo warunkowaną innowacyjnością. Sekcje te uznać więc można za motoryczne jednostki wzrostu w polskiej gospodarce. Należą do nich nowoczesne dziedziny usługowe: informacja i komunikacja (J), finanse i ubezpieczenia (K), a także usługi profesjonalne (M). Sytuacja ta potwierdza obecność tendencji do rozwoju usługowej gospodarki opartej na wiedzy w Polsce.

Badania zwracają również uwagę na odmienny charakter zmian produktywności poszczególnych czynników wytwórczych. W badanym okresie poprawę średniej dla wszystkich sekcji produktywności odnotowano wyłącznie w odniesieniu do wykorzystania pracy prostej. Może to wynikać ze wzrostu technicznego uzbrojenia pracy, jak i z wykorzystania zewnętrznych efektów wiedzy. Potwierdza to zaobserwowany w analizowanym okresie wzrost skali zaangażowania zarówno kapitału fizycznego, jak i ludzkiego. Kapitał ludzki i fizyczny, pomimo spadku produktywności, odnotowały natomiast pozytywne zmiany efektywności technicznej wynikające ze wzrostu efektywności skali. Wydaje się więc, że obecny etap zmian struktury wykorzystania czynników wytwórczych w Polsce przyjmuje raczej charakter ekstensywnego rozszerzania skali wykorzystania wiedzy, zaś wzrost intensywności wykorzystania czynników wiedzochłonnego rozwoju ma charakter wstępny. Potwierdza to pozycję polskiej gospodarki jako kraju doganiającego najbardziej zaawansowane gospodarki UE i świata. 


\section{Literatura \\ References}

Ahmed, E.M., Krishnasamy, G. (2013). Human Capital Investment to Achieve Knowledge-Based Economy in ASEAN5: DEA Applications. J Knowl Econ, 4, 331-342. DOI: 10.1007/s13132011-0059-2

Badunenko, O., Romero-Ávila, D. (2015). Productivity Growth across Industries and Regions: A Production-Frontier Approach Applied to the Spanish Case. Pozyskano z: http://www.alde. es/fotosbd/120620151100331636.pdf

Bassem, B.S. (2014). Total factor productivity change of MENA microfinance institutions: A Malmquist productivity index approach. Economic Modelling, 39, 182-189. DOI: 10.1016/j. econmod.2014.02.035

Chou, Y.-Ch., Shao, B.B.M. (2014). Total factor productivity growth in information technology services industries: A multi-theoretical perspective. Decision Support Systems, 62, 106-118. DOI: 10.1016/j.dss.2014.03.009

Clark, C. (1940). The Conditions of Economic Progress. London: Macmillan And Co. Limited.

Coelli, T. (1996). A Guide to DEAP Version 2.1: A Data Envelopment Analysis (Computer) Program. CEPA Working Paper, 96/08, 1-49.

Ćwiąkała-Małys, A., Nowak, W. (2011). Dekompozycja indeksu produktywności Malmquista w modeu DEA. Acta Universitatis Wratislaviensis, 3322, 273-284.

Diewert, W.E. (2015). Decompositions of productivity growth into sectoral effects. Journal of Productivity Analysis, 43, 367-387. DOI: 10.1007/s11123-014-0392-0

Eurostat (2018, 28 sierpnia). Baza danych statystycznych. National accounts employment data by industry (up to NACE A*64) [nama_10_a64_e]. National accounts aggregates by industry (up to NACE A*64) [nama_10_a64]. Employed HRST by category, age and NACE Rev. 2 activity (from 2008 onwards) [hrst_st_nsec2]. Pozyskano z https://ec.europa.eu/eurostat/ data/database

Färe, R., Grosskopf, S., Norris, M., Zhang, Z. (1994). Productivity Growth, Technical Progress, and Efficiency Change in Industrialized Countries. The American Economic Review, 84(1), 66-83.

Fisher, A.G.B. (1935). The Clash of Progress and Security. London: Macmillan.

Fura, B. (2017). Identyfikacja kluczowych sektorów polskiej gospodarki z wykorzystaniem analizy input-output. Studia i Prace Wydziału Nauk Ekonomicznych i Zarządzania Uniwersytetu Szczecińskiego, 47/2, 41-53. DOI: 10.18276/sip.2017.47/2-04

Gitto, S., Mancuso, P. (2015). The contribution of physical and human capital accumulation to Italian regional growth: a nonparametric perspective. Journal of Productivity Analysis, 43, 1-12. DOI: $10.1007 / \mathrm{s} 11123-013-0362-y$

Guzik, B. (2009). Podstawowe modele DEA w badaniu efektywności gospodarczej i społecznej. Poznań: Wydawnictwo Uniwersytetu Ekonomicznego w Poznaniu.

Kaasa, A. (2016). Social Capital, Institutional Quality and Productivity: Evidence from European Regions. Economics and Sociology, 9(4), 11-26. DOI: 10.14254/2071-789X.2016/9-4/1

Margaritis, D., Färe, R., Grosskopf, Sh. (2007). Productivity, convergence and policy: a study of OECD countries and industries. Journal of Productivity Analysis, 28, 87-105. D0I: 10.1007/ s11123-007-0044-

Murray, A. (2016). Partial versus Total Factor Productivity Measures: An Assessment of their Strengths and Weaknesses. International Productivity Monitor, 31, 113-126.

Silva, E.G., Teixeira, A.A.C. (2008). Surveying Structural Change: Seminal Contributions and a Bibliometric Account. Structural Change and Economic Dynamics, 19, 273-300. DOI: 10.1016/j.strueco.2008.02.001

Tanase, I., Tidor, A. (2012). Efficiency Progress and Productivity Change in Romania Machinery Industry 2001-2010. Procedia Economics and Finance, 3, 1055-1062. DOI: 10.1016/S22125671(12)00273-0

Magdalena Cyrek, dr, adiunkt, Uniwersytet Rzeszowski, Wydział Ekonomii, Katedra Mikroekonomii. Zainteresowania badawcze autorki koncentrują się na zmianach strukturalnych w gospodarce w układzie przekształceń sektorowo-branżowych oraz ich związkach z poziomem spójności społeczno-ekonomicznej. W szczególności autorka prowadzi badania nad problemami rozwoju sektora usług oraz gospodarki opartej 
na wiedzy w kontekście ich wpływu na nierówności ekonomiczne. Zakres zainteresowań naukowych obejmuje również makroekonomiczne problemy rynku pracy, rozwoju kapitału ludzkiego, innowacyjności oraz produktywności.

Magdalena Cyrek, PhD, University of Rzeszów, Faculty of Economics, Department of Microeconomics. Research interest of the author is focused on structural changes in economy concerning sectoral and branch dimension and their relations with a level of socio-economic cohesion. Especially, the author conducts research on problems of services sector and knowledge-based economy development in the context of their influence on economic inequality. The research covers also macroeconomic problems of labour market, development of human capital, innovativeness and productivity.

ORCID: 0000-0001-5020-9273

\section{Adres/address:}

Uniwersytet Rzeszowski

Wydział Ekonomii

Katedra Mikroekonomii

ul. M. Ćwiklińskiej 2, 35-601 Rzeszów, Polska

e-mail: mcyrek@ur.edu.pl 